\title{
HUBUNGAN KONDISI FISIK RUMAH DAN TINGKAT EKONOMI ORANGTUA TERHADAP KEJADIAN PNEUMONIA PADA BALITA (Studi Kasus di Wilayah Kerja Puskesmas Sukodono)
}

Diaz Ramadhani*, Nurhaidah, Narwati

Jurusan Kesehatan Lingkungan Poltekkes Kemenkes Surabaya *Email korespondensi: diazramadhani8@gmail.com

\begin{abstract}
ABSTRAK
Pneumonia pada balita masih menjadi salah satu penyebab kematian tertinggi di dunia. Kematian karena pneumonia pada masa kanak-kanak sangat terkait dengan faktor yang berhubungan dengan kemiskinan seperti kurang gizi, polusi udara dalam ruangan, dan akses yang tidak memadai ke perawatan kesehatan. Tujuan penelitian ini untuk mengetahui hubungan antara kondisi fisik rumah dan tingkat ekonomi orangtua dengan kejadian pneumonia pada balita di wilayah kerja Puskesmas Sukodono.

Penelitian ini merupakan penelitian observasional analitik menggunakan studi Case Control. Sebanyak 25 rumah balita menderita pneumonia sebagai kasus dan 25 rumah balita tidak menderita pneumonia sebagai kontrol. Responden penelitian ini adalah ibu balita kelompok kasus maupun kontrol. Data yang diperoleh dianalisis secara univariat dan bivariat dengan uji Chi Square.

Hasil analisis menunjukkan dari lima variabel yang diteliti, dua variabel memiliki hubungan bermakna dengan kejadian pneumonia pada balita, yaitu kepadatan kamar tidur $(p=0,027)$ dan kelembaban rumah $(p=0,030)$, sedangkan variabel pencahayaan alami $(p=0,172)$, suhu rumah $(0,382)$, dan tingkat ekonomi orangtua $(p=0,349)$ tidak memiliki hubungan dengan kejadian pneumonia pada balita.

Kesimpulan penelitian ini yaitu ada hubungan antara kepadatan kamar tidur dan kelembaban rumah dengan kejadian pneumonia pada balita, sedangkan suhu rumah, pencahayaan alami, dan tingkat ekonomi orangtua tidak memiliki hubungan dengan kejadian pneumonia pada balita. Saran bagi masyarakat untuk ikut berperan dalam mencegah penularan penyakit pneumonia dengan rajin membuka jendela rumah tiap hari dan kamar tidur maksimal dihuni oleh 2 orang dewasa dan 1 balita dengan luas minimal $8 \mathrm{~m}^{2}$. Saran bagi puskesmas untuk meningkatkan pengetahuan tentang penyakit pneumonia pada ibu dengan penyuluhan dan pembinaan sanitasi rumah.
\end{abstract}

Kata kunci: Pneumonia, Kondisi Fisik Rumah, Tingkat Ekonomi Orangtua

\section{PENDAHULUAN}

Pneumonia merupakan bentuk infeksi pernapasan akut yang menyerang kantung-kantung kecil pada paru-paru, yang disebut alveoli. Pada penderita pneumonia, alveoli dipenuhi dengan nanah dan cairan, sehingga pernafasan terasa menyakitkan dan asupan oksigen menjadi terbatas (WHO,2019).

Data UNICEF tahun 2019 menyatakan setiap tahunnya ada lebih dari 800.000 anak balita, atau sekitar 2.200 tiap harinya yang kehilangan nyawa akibat pneumonia. Dari 100.000 anak di seluruh dunia, lebih dari 1.400 anak menderita pneumonia, atau dari 7 anak, ditemukan 1 anak penderita pneumonia setiap tahun, dimana jumlah kasus terbesar berada di Asia Selatan (2.500 kasus per 100.000 anak) dan
Afrika Barat serta Afrika Tengah (1.620 kasus per 100.000 anak).

Balita penderita Pneumonia di Jawa Timur pada tahun 2017 diperkirakan sebanyak 127.734 kasus, dimana 86.358 kasus telah ditemukan dan ditangani. Kasus tersebut menyebar di 38 Kabupaten/Kota dimana kasus tertinggi berada di Kabupaten Sidoarjo sebanyak 8.747 kasus. Profil Kesehatan Kabupaten Sidoarjo Tahun 2017 menyatakan, 8.597 penderita pneumonia di Kabupaten Sidoarjo telah ditemukan dan ditangani. Kasus tertinggi berada di Puskesmas Sukodono sebanyak 709 kasus.

Jumlah balita penderita pneumonia di Puskesmas Sukodono pada tahun 2018 sebanyak 610 penderita dan selama Januari - Oktober 2019 sebanyak 502 penderita. 
Rumah Sehat merupakan bangunan tempat tinggal yang telah memenuhi syarat kesehatan, baik dari komponen rumah, sarana sanitasi dan perilaku, antara lain memiliki jamban sehat, tempat pembuangan sampah, sarana air bersih, sarana pembuangan air limbah, ventilasi baik, kepadatan hunian rumah sesuai, serta lantai rumah tidak terbuat dari tanah (Profil Kesehatan Kabupaten Sidoarjo, 2017).

$\begin{array}{ccr}\text { Keluarga } & \text { dengan tingkat } \\ \text { pendapatan yang tinggi dapat }\end{array}$ mendukung untuk melakukan upaya pencegahan terhadap kejadian pneumonia pada balita. Selain itu, keluarga dengan pendapatan yang tinggi akan mampu menyediakan tempat tinggal yang layak huni dan memenuhi persyaratan rumah sehat (Suryati,dkk. 2018).

Tujuan dari penelitian ini yaitu untuk menganalisis hubungan antara kondisi fisik rumah dan tingkat ekonomi orangtua dengan kejadian penyakit Pneumonia pada balita di wilayah kerja Puskesmas Sukodono.

\section{METODE PENELITIAN}

Penelitian dilakukan dengan metode observasional analitik menggunakan studi Case Control. Populasi diambil dari seluruh rumah balita penderita pneumonia di wilayah kerja Puskesmas Sukodono pada tahun 2019 sebesar 502 rumah.

Penelitan ini menggunakan rumus (Hidayat, 2018) untuk menentukan besar sampel, sehingga diperoleh sampel kasus 25 rumah balita penderita pneumonia dan 25 rumah balita kontrol. Pelaksanaan penelitian dilakukan pada 18 rumah balita penderita pneumonia dan 25 rumah balita kontrol. Hal tersebut dikarenakan terbatasnya akses ke rumah penderita.

Pengambilan sampel menggunakan teknik simple random sampling, sedangkan pengumpulan data melalui wawancara dan pengukuran kondisi fisik rumah responden. Data dianalisis menggunakan metode Uji Chi Square. $\mathrm{HO}$ ditolak jika $\mathrm{p}<\mathrm{a}$ yang berarti ada hubungan antar variabel.

\section{HASIL DAN PEMBAHASAN}

Tabel 1

Karakteristik Sampel Berdasarkan Jenis Kelamin, Usia, dan Pekerjaan Orangtua

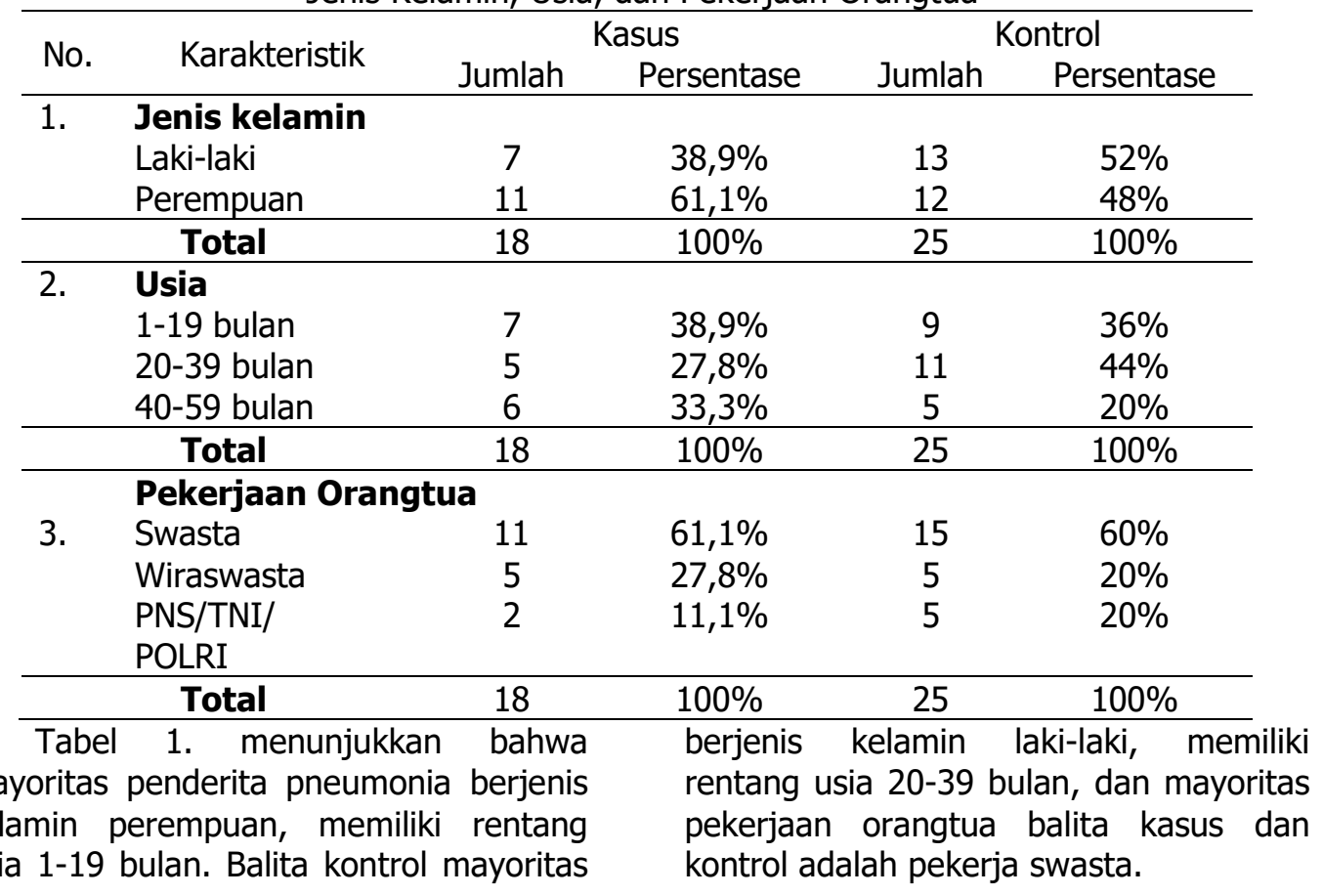


Tabel 2

Distribusi Frekuensi Kepadatan Kamar Tidur Balita di Kecamatan Sukodono Tahun 2020

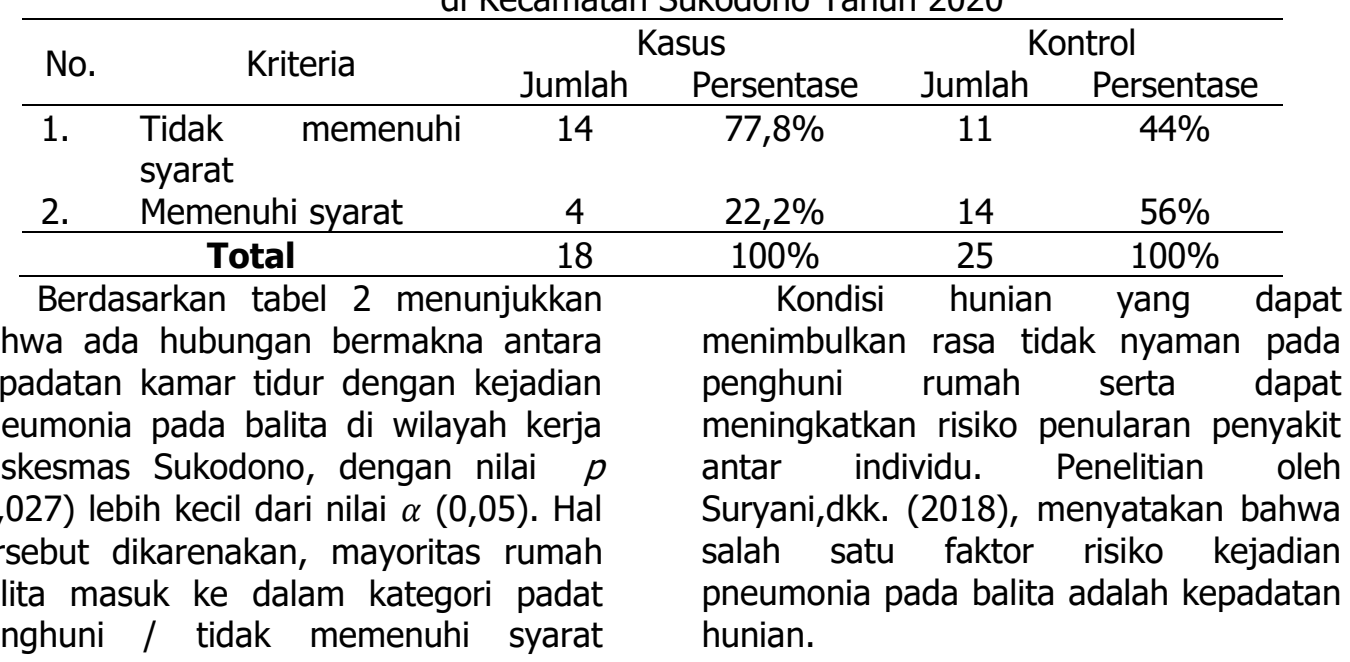

karena dihuni lebih dari 3 orang.

Tabel 3

Distribusi Frekuensi Pencahayaan Alami Rumah Balita di Kecamatan Sukodono Tahun 2020

\begin{tabular}{|c|c|c|c|c|}
\hline \multirow{2}{*}{ No. } & \multirow{2}{*}{ Kriteria } & \multicolumn{2}{|c|}{ Kasus } & Kontrol \\
\hline & & Jumlah & Persentase & Persentase \\
\hline 1. & $\begin{array}{l}\text { Tidak memenuhi } \\
\text { syarat }\end{array}$ & 11 & $61,1 \%$ & $40 \%$ \\
\hline 2. & Memenuhi syarat & 7 & $38,9 \%$ & $60 \%$ \\
\hline & Total & 18 & $100 \%$ & $100 \%$ \\
\hline $\begin{array}{l}\text { Berc } \\
\text { ya }\end{array}$ & $\begin{array}{l}\text { arkan tabel } 3 \text { menu } \\
\text { bungan antara penc } \\
\text { h dengan kejadian pne } \\
\text { di wilayah kerja Pus } \\
\text { dengan nilai } p(0,17 \\
\text { nilai } \alpha(0,05) \text {. M } \\
\text { a penderita pneumon } \\
\text { jendela/gorden setia } \\
\text { berada di gang yan } \\
\text { dan kondisi kamar tid }\end{array}$ & $\begin{array}{l}\text { Jkkan } \\
\text { ayaan } \\
\text { monia } \\
\text { lebih } \\
\text { oritas } \\
\text { tidak } \\
\text { pagi } \\
\text { padat } \\
\text { yang }\end{array}$ & $\begin{array}{l}\text { Sinar matahari } \\
\text { dalam rumah dapat } \\
\text { pencahayaan alami } \\
\text { meningkatkan kele } \\
\text { Penelitian ini sejalan } \\
\text { oleh Anggiani,dkk. } \\
\text { menyatakan bahwa ti } \\
\text { antara pencahayaan a } \\
\text { kejadian pneumonia } \\
\text { wilayah kerja Pu } \\
\text { Kabunaten Pati }(\mathrm{D}=0\end{array}$ & $\begin{array}{l}\text { yang masuk } \\
\text { berfungsi sebas } \\
\text { dan juga unt } \\
\text { mbaban ruma } \\
\text { dengan peneliti } \\
\text { (2016), ya } \\
\text { dak ada hubung } \\
\text { ami rumah deng } \\
\text { pada balita } \\
\text { kesmas Pati } \\
\text { 61) }\end{array}$ \\
\hline
\end{tabular}

seperti ventilasi maupun jendela.

Tabel 4

Distribusi Frekuensi Kelembaban Rumah Balita di Kecamatan Sukodono Tahun 2020

\begin{tabular}{|c|c|c|c|c|c|}
\hline \multirow{2}{*}{ No. } & \multirow{2}{*}{ Kriteria } & \multicolumn{2}{|c|}{ Kasus } & \multicolumn{2}{|c|}{ Kontrol } \\
\hline & & Jumlah & Persentase & Jumlah & Persentase \\
\hline 1. & $\begin{array}{ll}\text { Tidak memenuhi } \\
\text { syarat }\end{array}$ & 11 & $61,1 \%$ & 7 & $28 \%$ \\
\hline 2. & Memenuhi syarat & 7 & $38,9 \%$ & 18 & $72 \%$ \\
\hline & Total & 18 & $100 \%$ & 25 & $100 \%$ \\
\hline
\end{tabular}

Tabel 4 menunjukkan adanya di wilayah kerja Puskesmas Sukodono, hubungan antara kelembaban rumah dengan nilai $p(0,030)$ lebih kecil dari dengan kejadian pneumonia pada balita nilai $\alpha(0,05)$. Hal tersebut dikarenakan, 
mayoritas rumah balita penderita memiliki kelembaban udara tidak memenuhi syarat $(>60 \%)$, sebaliknya pada kelompok kontrol sebagian besar memenuhi syarat $(\leq 60 \%)$.

Kelembaban udara $>60 \%$ dapat memicu pertumbuhan bakteri sehingga penghuni rumah lebih rentan tertular penyakit. Kusumawati,dkk. (2015), menjeleskan bahwa terdapat hubungan bermakna antara tingkat kelembaban rumah dengan pneumonia balita, dimana nilai $p$-value $=0,017$.

Tabel 5

Distribusi Frekuensi Suhu Rumah Balita di Kecamatan Sukodono Tahun 2020

\begin{tabular}{llcccc}
\hline \multirow{2}{*}{ No. } & \multicolumn{2}{c}{ Kriteria } & \multicolumn{2}{c}{ Kasus } & \multicolumn{2}{c}{ Kontrol } \\
& Jumlah & Persentase & Jumlah & Persentase \\
\hline 1. & $\begin{array}{l}\text { Tidak memenuhi } \\
\text { syarat }\end{array}$ & 3 & $16,7 \%$ & 2 & $8 \%$ \\
2. & Memenuhi syarat & 15 & $83,3 \%$ & 23 & $92 \%$ \\
\hline \multicolumn{2}{c}{ Total } & 18 & $100 \%$ & 25 & $100 \%$
\end{tabular}

Berdasarkan tabel 5 menunjukkan tidak adanya hubungan bermakna antara suhu rumah dengan kejadian pneumonia pada balita di wilayah kerja Puskesmas Sukodono, dengan nilai $p(0,382)$ lebih besar dari nilai $\alpha \quad(0,05)$. Hal ini dikarenakan sebagian besar orangtua balita selalu membuka jendela rumah di pagi hari, sehingga sirkulasi udara menjadi lancar (memenuhi syarat). Hal ini sama keadaannya dengan kelompok kontrol yang sebagian besar juga memenuhi syarat.
Suhu udara yang tinggi dapat menyebabkan ruangan menjadi panas dan pengap sehingga menimbulkan rasa tidak nyaman bagi penghuni rumah, maka sebagian menggunakan AC atau kipas angin. Istihoroh,dkk. (2018), yang menjelaskan bahwa tidak terdapat hubungan bermakna antara suhu udara dengan kejadian penyakit ISPA di wilayah kerja Puskesmas Kadur Kabupaten Pamekasan.

Tabel 6

Distribusi Frekuensi Tingkat Ekonomi Orangtua Balita di Kecamatan Sukodono Tahun 2020

\begin{tabular}{|c|c|c|c|c|c|}
\hline \multirow[b]{2}{*}{ No. } & \multirow{2}{*}{ Kriteria } & \multicolumn{2}{|c|}{ Kasus } & \multicolumn{2}{|c|}{ Kontrol } \\
\hline & & Jumlah & Persentase & Jumlah & Persentase \\
\hline 1. & Rendah & 0 & $0 \%$ & 0 & $0 \%$ \\
\hline 2. & Sedang & 5 & $27,8 \%$ & 4 & $16 \%$ \\
\hline 3. & Cukup & 6 & $33,3 \%$ & 6 & $24 \%$ \\
\hline 4. & Tinggi & 7 & $38,9 \%$ & 15 & $60 \%$ \\
\hline & Total & 18 & $100 \%$ & 25 & $100 \%$ \\
\hline
\end{tabular}

Berdasarkan tabel 6 menjelaskan tidak adanya hubungan bermakna antara tingkat ekonomi orangtua dengan kejadian pneumonia pada balita di wilayah kerja Puskesmas Sukodono, dengan nilai $p(0,349)$ lebih besar dari nilai $\alpha(0,05)$. Hal tersebut dikarenakan orangtua balita penderita pneumonia dan orangtua balita kontrol memiliki tingkat ekonomi sedang - tinggi.
Tingkat ekonomi keluarga berperan penting dalam kelangsungan hidup sebuah keluarga. Tingkat ekonomi keluarga berperan dalam memenuhi kebutuhan hidup, baik kebutuhan pokok, kebutuhan akan pelayanan kesehatan, hingga kebutuhan tambahan lainnya. Rahmawati,dkk (2014) menjelaskan bahwa tidak adanya hubungan yang signifikan antara pendapatan keluarga dengan kejadian pneumonia pada balita $(p=0,194)$. 


\section{KESIMPULAN}

Sebanyak 22,2\% kepadatan kamar tidur balita penderita pneumonia telah memenuhi syarat, dan $77,8 \%$ tidak memenuhi syarat, sedangkan pada balita kontrol sebanyak $56 \%$ telah memenuhi syarat dan. Suhu rumah balita penderita pneumonia yang memenuhi syarat sebanyak $83,3 \%$, pada kontrol sebanyak $92 \%$. Pencahayaan alami rumah balita penderita pneumonia yang memenuhi syarat sebanyak $38,9 \%$, sedangkan pada control sebanyak $60 \%$. Kelembaban udara rumah balita penderita pneumonia yang memenuhi syarat sebanyak $38,9 \%$, sedangkan pada kontrol yang memenuhi syarat sebanyak $72 \%$.

Dari 5 variabel yang diteliti, variabel kepadatan kamar tidur dan kelembaban rumah memiliki hubungan bermakna dengan kejadian pneumonia pada balita. Pada variabel suhu rumah, pencahayaan alami, dan tingkat ekonomi orangtua tidak memiliki hubungan bermakna dengan kejadian pneumonia pada balita.

\section{SARAN}

\section{Bagi Masyarakat}

Masyarakat hendaknya ikut berperan dalam mencegah penularan penyakit, khususnya pneumonia pada balita dengan menciptakan kondisi rumah yang bersih, sehat, nyaman, dan aman untuk dijadikan tempat tinggal. Hal tersebut dapat tercipta melalui beberapa tindakan, diantaranya :

a. Kamar tidur hendaknya hanya dihuni oleh maksimal 2 orang dewasa dan 1 balita dengan luas minimal $8 \mathrm{~m}^{2}$.

b. Rajin membuka jendela rumah tiap pagi hari agar rumah memiliki pencahayaan yang baik dan sirkulasi udara menjadi lancar.

\section{Bagi Puskesmas Sukodono}

Petugas kesehatan tetap memrogramkan peningkatan pengetahuan masyarakat, khususnya ibu terkait kesehatan lingkungan, terkait sanitasi pemukiman/sanitasi rumah sehat dan pengetahuan pneumonia. Upaya tersebut dapat diterapkan dengan cara penyuluhan oleh petugas kesehatan pada saat kegiatan sosial seperti posyandu, PKK, pengajian, dan kegiatan lainnya.

\section{Bagi Peneliti Lain}

Peneliti lain diharapkan bisa melakukan penelitian terkait faktor faktor risiko lainnya yang berhubungan dengan kejadian pneumonia pada balita (seperti malnutrisi, kurang mendapatkan ASI eksklusif, imunisasi campak tidak lengkap, lahir prematur, imunosupresi, infeksi HIV, status ekonomi keluarga rendah, kondisi komorbiditas, akses terhadap pelayanan kesehatan tidak terjangkau, kepadatan penduduk, membawa anak ke dapur saat memasak, status gizi, serta kondisi fisik rumah) menggunakan teknik dan metode yang berbeda.

\section{DAFTAR PUSTAKA}

Anggiani Dinda Rahma, Suhartono, Nikie Astorina Yunita Dewanti. 2016. Hubungan Kondisi Lingkungan Dalam Rumah Dengan Kejadian Pneumonia Pada Balita Di Wilayah KerjaPuskesmas Pati I Kabupaten Pati. Semarang. Jurnal Kesehatan Masyarakat (e-Journal) Volume 4 Nomor 3, Juli 2016.

Dinas Kesehatan Kabupaten Sidoarjo. 2018. Profil Kesehatan Kabupaten Sidoarjo Tahun 2017. Sidoarjo.

Dinas Kesehatan Provinsi Jawa Timur. 2018. Profil Kesehatan Jawa Timur Tahun 2017. Surabaya.

Hidayat, A. Aziz Alimul. 2018. Metodologi Penelitian Keperawatan dan Kesehatan. Jakarta. Salemba Medika.

Istihoroh Yeni Rohmatul, Umi Rahayu, Pratiwi Hermiyanti. 2018. Hubungan Kondisi Fisik Rumah dengan Kejadian Penyakit Infeksi Saluran Pernafasan Akut (ISPA) di Wilayah 
Kerja Puskesmas Kadur Kabupaten Pamekasan Tahun 2017. Surabaya. Gema Kesehatan Lingkungan Volume 16 No. 1 April 2018.

Kusumawati Diah, Suhartono, Nikie Astorina Yunita D. 2015. Hubungan Kondisi Lingkungan Fisik Rumah dan Perilaku Anggota Keluarga dengan Kejadian Pneumonia Pada Balita (Studi Kasus di Wilayah Kerja Puskesmas Magelang Selatan Kota Magelang). Semarang. Jurnal Kesehatan Masyarakat (e-Journal) Volume 3 Nomor 3, April 2015.

Rahmawati Okti, Diffah Hanim, Sumardiyono. 2014. Hubungan Faktor Sosial Ekonomi dengan Kejadian Pneumonia pada Anak Bawah Lima Tahun di Surakarta. Nexus Kedokteran Komunitas Volume 3/No.1/April/2014

Suryani, Suharyo Hadi Saputro, dan Sidartani Zain. 2018. Faktor Risiko Lingkungan yang Berhubungan dengan Kejadian Pneumonia pada Balita (Studi di Wilayah Kerja Dinas Kesehatan Kota Bengkulu).
Bengkulu. Program Studi Kesehatan Masyarakat STIKES Tri Mandiri Sakti.

Suryati, Nyimas Natasya, dan Nur Id'ys. 2018. Hubungan Faktor Lingkungan Fisik dan Sosial Ekonomi Keluarga Terhadap Kejadian Pneumonia pada Balita di Wilayah Kerja Puskesmas Tahlul Yaman Kota Jambi. Jambi. Jurnal Daur Lingkungan Universitas Batanghari

UNICEF. $2019 . \quad$ Pneumonia. (https://data.unicef.org/topic/childhealth/pneumonia/). Diakses pada 19 November 2019.

WHO. 2019.2 Pneumonia. (https://www.who.int/newsroom/fact-sheets/detail/pneumonia). Diakses pada 20 November 2019. 